Ана Голубовић

Универзитет у Београду

Филолошки факултет

Катедра за славистику

slavistika@fil.bg.ac.rs
УДК 012

https://doi.org/10.18485/slavistika.2020.24.1.2

Информативни прилог примљено 21.03.2020.

прихваћено за штампу 21.05.2020.

\title{
БИБЛИОГРАФИЈА РАДОВА ПРОФ. ДР БОБАНА ЋУРИЋА
}

\section{Књиге}

1. Из живота руског Београда. - Београд : Филолошки факултет, 2011. - 171 стр. - (Монографије)

2. Из жизни русского Белграда. - Белград : Филологический факультет Белградского университета, 2015. - 230 стр. - (Библиотека Язык и литература, серия Русская эмиграция в Белграде ; 6)

3. Руска емиграција. - Бања Лука : Бина д.о.о., 2019. - 249 стр.

\section{Дисертације}

1. Руска књижевност у београдском дневном листу „Правда” : 1917-1941. : магистарски рад. - Београд, 1999. - 327 лист.

2. Романи Бориса Савинкова (В. Ропшина) : докторска дисертација. - Београд, 2013. - 513 лист.

\section{Чланци}

1. „Песма остаје с човеком - Шагане моја, Шагане...” / „Песня остается с человеком - Шаганэ ты моја, Шаганэ...” / Тимура Кибирова : разговор с Јесењином // Зборник Матице српске за славистику. - Бр. 50/51 (1996), стр. 185-191.

2. Библейские мотивы в рассказе Льва Лунца „В пустыне” // Русская литература. - Бр. 2 (1998), стр. 131-136.

3. Библейские мотивы в рассказе „Родина” Льва Лунца // Филолошки преглед. - Бр. 25, св. 1 (1998), стр. 151-164.

4. „Кесарь и Галилеянин” Генриха Ибсена и „Юлиан Отступник” Д. С. Мережковского : попытка сопоставительного анализа // Западноевропейският модернизъм и славянските литератури : краят на XIX - началото на XX век и 20-те години : материалы от Международна научна конференция... 8-10.V.1997 г. / ур. М. Каназирска. - Велико Търново : Университетско издателство „Св. св. Кирил и Методий”, 1999. - Стр. 175-186.

5. Обележавање стогодишњице смрти А. С. Пушкина 1937. године : на материјалу београдског дневног листа „Правда” // Славистика. - Бр. 3 (1999), стр. 40-50.

6. Гостовања руских емигрантских писаца у Београду током 20-тих и 30-тих година XX века : на материјалу београдског дневног листа „Правда” // Зборник 
Матице српске за славистику. - Бр. 61 (2002), стр. 119-153.

7. Београдска периодика између два рата о стваралаштву Д. С. Мерешковског у емиграцији // Зборник Матице српске за славистику. - Бр. 63 (2003), стр. 307-341.

8. Гостовање К. Д. Баљмонта у Београду 1929. године : на материјалу дневне штампе // Славистика. - Бр. 7 (2003), стр. 328-336.

9. Путовање кроз време и простор у роману „Коњаникова сенка” А. Гладилина // Пут и путовање у уметности и култури. - Београд : Филолошки факултет, 2003. - Стр. 245-258.

10. Крушение музея или о некоторых мотивах философии Н. Федорова в „Котловане” А. Платонова // Философия космизма и русская культура : материалы международной научной конференции „Космизм и русская литература : к 100-летию со дня смерти Николая Федорова", 23-25 октября 2003 г.). - Белград : Филологический факультет, 2004. - Стр. 245-249.

11. Обележавање стогодишњице рођења Л. Н. Толстоја у Београду 1928. године // Славистика. - Бр. 8 (2004), стр. 193-200.

12. Гибель эпохи : гибель мира в „Комедии города Петербурга” Д. Хармса / [коаутор] Ана Јаковљевић // Russian Literature. - Бр. 60, св. 3/4 (2006), стр. 459-465.

13. Гибель эпохи : гибель мира в „Комедии города Петербурга” Д. Хармса / [коаутор] Ана Јаковљевић // Хармс-авангард : материалы международной научной конференции „Даниил Хармс : авангард в действии и в отмирании : к 100-летию со дня рождения поэта", (Филологический факультет, Белград, 14-18 декабря 2005 г.). - Белград : Филологический факультет, 2006. - Стр. 411-416.

14. Драма „Царевић Алексеј” Мерешковског на сцени Народног позоришта : на материјалу београдске периодике // Филолошки преглед. - Бр. 33, св. 1 (2006), стр. 167-176.

15. Конгрес руских писаца и новинара у емиграцији и његово место у српској и руској култури // Славистика. - Бр. 10 (2006), стр. 313-324.

16. Легенда о Светом гралу и драма „Ружа и крст” Александра Блока // Зборник Матице српске за славистику. - Бр. 70 (2006), стр. 57-71.

17. Буњин 1937. године у Београду // Руска дијаспора и српско-руске културне везе : зборник реферата / ур. Б. Станковић. - Београд : Славистичко друштво Србије, 2007. - Стр. 115-122. - (Славистичка библиотека : посебна издања)

18. Из духовног живота руског Београда // Славистика. - Бр. 11 (2007), стр. 383-387.

19. Јуриј Ракитин режира драму Мерешковског „Царевић Алексеј” : на материјалу београдске периодике // Јуриј Љвович Ракитин : живот, дело, сећања : зборник радова међународног научног скупа „Јуриј Љвович Ракитин : живот, дело, сећања", Београд, Нови Сад, 17-20. априла 2003. / ур. Е. Успенски, А. Арсењев, 3. Максимовић. - Нови Сад : Позоришни музеј Војводине ; Београд : Факултет драмских уметности, 2007. - Стр. 279-283.

20. Руски слависти-емигранти са књижевним темама у материјалима III међународног конгреса слависта // Славистика. - Бр. 12 (2008), стр. 408-410. 
21. Русский дом в Белграде : по поводу 75-летия работы Дома // Изучавање словенских језика, књижевности и култура као инословенских и страних : зборник реферата : међународни симпозијум посвећен 130-годишњици Катедре за руски језик и књижевност и 60-годишњици Славистичког друштва Србије, Београд, (3-5. јун 2008) / ур. Б. Станковић. - Београд : Славистичко друштво Србије, 2008. - Стр. 367-373.

22. Уместо предговора // Распућин и друге приче / Надежда Александровна Тефи. - Београд : Нолит, 2008. - Стр. 5-13.

23. Храм русской культуры в Белграде // Этносфера. - Бр. 5 (2009), стр. 20-22.

24. Русская эмиграция в защиту русского языка : „Памятка” белградского Союза ревнителей чистоты русского языка (1937 г.) // Русский язык как инославянский. - Бр. 2 (2010), стр. 96-102.

25. Библијски подтекст у роману „Коњ блед” Бориса Савинкова // Антички код у словенским књижевностима. - Београд : Филолошки факултет, 2011. Стр. 51-71.

26. Идея террора и творчество Бориса Савинкова // Русская философия сегодня : об искусстве и политике. - Белград : Филологический факультет, 2011. - Стр. 65-79.

27. Борис Савинков (В. Ропшин) и стваралаштво Достојевског // Славистика. - Бр. 16 (2012), стр. 585-598.

28. Записки Русского научного института в Белграде // Русское зарубежье и славянский мир : сборник трудов. - Белград : Славистическое общество Сербии, 2013. - Стр. 303-317.

29. Библијски мотиви у роману „Коњ вран” Б. Савинкова (В. Ропшина) // Славистика. - Бр. 18 (2014), стр. 400-407.

30. „Коњ блед” Савинкова-Ропшина и традиција нихилизма у руској култури // Зборник Матице српске за славистику. - Бр. 85 (2014), стр. 53-68; Бр. 86 (2014), стр. 99-108.

31. Русская эмиграция в Белграде // Вестник Нижегородского государственного лингвистического университета им. Н.А. Добролюбова. - Бр. 26 (2014), стр. 141-168.

32. Марк Слоњим : сарадник „Руског архива” // Часопис „Руски архив” (1928-1937) и култура руске емиграције у Краљевини СХС/Југославији : зборник радова / ур. В. Матовић. - Београд : Институт за књижевност и уметност, 2015. - Стр. 267-285. - (Серија Историја српске књижевне периодике ; 27)

33. Тема Москве у роману „Коњ вран” Б. Савинкова (В. Ропшина) // Славистика. - Бр. 19 (2015), стр. 418-424.

34. Белградская периодическая печать о Д. С. Мережковском в эмиграции : 1921-октябрь 1928. // Русская литература и журналистика в движении времени. - Бр. 2 (2016), стр. 181-211.

35. Роман „Коњ блед” Б. Савинкова (В. Ропшина) и немачка субјективистичка филозофија // Славистика. - Бр. 20 (2016), стр. 498-509.

36. Русский дом в Белграде : история строительства и первоначаль- 
ная структура Русского дома в Белграде / [коаутор] Ирина Антанасијевић // Вспомогательные исторческие дисциплины в современном научном знании : материалы XXVIII Международной научной конференции, Москва, 14-16 апреля 2016 г. - Москва : Аквилон, 2016. - Стр. 108-113.

37. Хоповски конгрес (1925) и делатност Руског судентског хришћанског покрета // Зборник Матице српске за славистику. - Бр. 89 (2016), стр. 203-222.

38. Белградская периодическая печать о Д. С. Мережковском в эмиграции : 1928-1939. // Русская литература и журналистика в движении времени. - Бр. 3 (2017), стр. 273-285.

39. Гостовања Игора Северјанина у Београду : 1930, 1931. и 1933. године // Славистика. - Бр. 21 (2017), стр. 286-297.

40. Из истории духовной жизни русской эмиграции в Сербии : Хоповский съезд (1925) и деятельность РСХД // Мултикултурализъм и многоезичие : сборник с доклади от Тринадесетите международни славистични четения, София, 21-23 април 2016 г. 2, Антропология, литературознание. - Велико Търново: Фабер, 2017. - Стр. 220-228.

41. „Конь бледный” Б. Савинкова (В. Ропшина) и идейное убийство : от события исторической реальности к событию в литературном произведении // Slavica Tergestina. - Бр. 18, св. 1 (2017), стр. 164-185.

42. Наличје револуције : роман „Коњ вран” Бориса Савинкова (В. Ропшина) // Летопис Матице српске. - Бр. 500, св. 4 (окт. 2017), стр. 500-513.

43. Писмо Бориса Савинкова краљу Александру Карађорђевићу : 1921. г. // Зборник Матице српске за славистику. - Бр. 91 (2017), стр. 217-229.

44. Гостовања Ј. Н. Чирикова у Београду 1928. и 1929. године // Славистика. - Бр. 22, св. 2 (2018), стр. 178-191.

45. Максим Горький на сцене белградского Национального театра между двумя мировыми войнами // Мировое значение творчества Горького : Горьковские чтения 2018 : материалы XXXVIII Международной научной конференции / ред. М. Г. Уртминцева. - Нижний Новгород : БегемотНН, 2018. - Стр. 135-142.

46. Писмо Бориса Савинкова краљу Александру Карађорђевићу : 1921. г. // Српско-руске књижевне и културне везе : епоха модерне / ур. К. Ичин. - Нови Сад : Матица српска, 2018. - Стр. 71-86.

47. А. И. Куприн у Београду 1928. године // Славистика. - Бр. 23, св. 1 (2019), стр. 235-247.

48. Революция как апокалипсис : историософская тема в романе „Конь вороной” Бориса Савинкова // Искусство и революция : сто лет спустя : сборник статей / ур. К. Ичин. - Белград : Филологический факультет, 2019. - Стр. $277-285$.

\section{Прикази и хронике}

1. Функции литературных связей : на материале славянских и балканских литератур (Институт славяноведения и балканологии, ПАН, Москва 1992) // Зборник Матице српске за славистику. - Бр. 44/45 (1993), стр. 283-284. 
2. Друга међународна конференција Књижевна група „Серапионова браћа” : извори, трагања, традиција, међународни контекст // Зборник Матице српске за славистику. - Бр. 52 (1997), стр. 352-353.

3. Међународна књижевна конференција „Западноевропски модернизам, рефлекси у Бугарској књижевности и књижевностима централне и источне Европе" // Зборник Матице српске за славистику. - Бр. 52 (1997), стр. 351-352.

4. Sine arte, nihil : сборник научных трудов в дар профессору Миливое Йовановичу (Белград, Москва, 2002) // Зборник Матице српске за славистику. Бр. 64 (2003), стр. 264-266.

5. Миливое Йованович: Избранные труды по поэтике русской литературы (Белград, 2004) // Зборник Матице српске за славистику. - Бр. 68 (2005), стр. 311-313.

6. В. П. Григорьев, Л. И. Колодяжная, Л. Л. Шестакова, Собственное имя в русской поэзии XX века (Москва, 2005) // Зборник Матице српске за славистику. - Бр. 74 (2008), стр. 347-348.

7. Русская диаспора и изучение русского языка и русской культуры в инославянском и иностранном окружении : доклады / ред. Б. Станкович (Белград : Славистическое общество Сербии, 2012) 336. // Русский язык как инославянский. - Бр. 4 (2012), стр.145-148.

8. Русское зарубежье и славянский мир : сборник трудов / сос. П. Буняк (Белград : Славистическое общество Сербии, 2013) 595. // Филолошки преглед. - Бр. XL, св. 2 (2013), стр. 149-154.

9. От чужих к своим : письма выдающихся представителей русской интеллигенции начала XX века Александру Беличу (Београд : Логос, 2016) 332. // Славистика. - Бр. 20 (2016), стр. 741-742.

10. От чужих к своим : письма выдающихся представителей русской интеллигенции начала XX века Александру Беличу (Београд : Логос, 2016) 332. // Зборник Матице српске за славистику. - Бр. 91 (2017), стр. 258-261.

\section{Преводи}

1. Хоћу да постанем Јукагир / Јегор Радов // Реч. - Бр. 1, св. 4 (1994), стр. 44-45.

2. „Руско питање” крајем 20. века / А. И. Солжењицин. - Нови Сад : Матица српска ; Београд : Цицеро ; Земун : Писмо, 1995. - 89 стр. - (Библиотека Писмо ; 25)

3. Живот с идиотом / Виктор Владимирович Ерофеев // Реч. - Бр. 3, св. 21 (1996), стр. 42-50.

4. Ћутање, Један дан са женом / Јегор Радов. Путовање пупка у ласу / Виктор Владимирович Ерофеев. Почетак сезоне / Владимир Сорокин // Реч. - Бр. 3, св. 28 (1996), стр. 43-47, 50-57.

5. Dokumenti za razumevanje ruske avangarde : antologija tekstova umetnika. Beograd : Geopoetika, 2003. - 292 str. - (Edicija Art)

6. В. Дудинцев, Новогодишња бајка; Ј. Нагибин, Светло у прозору; Ф. Горенштејн, Старице; В. Аксјонов, Доручак четрдесет треће године, Риђокоси 
из суседног дворишта; В. Војнович, Растојање од пола километра, Цртица // На пола пута до месеца : од Паустовског до Војновича / ур. М. Јовановић. Београд : Плато, 2004. - Стр. 202-239, 405-421, 442-489. - (Антологија руске приче XX века ; 2, 1) (Библиотека Психократия)

7. В. Белов, Дан за даном; В. Марамзин, Ја, са шамаром у руци; Вик. Јерофејев, Путовање пупка у Ласу; В. Сорокин, Почетак сезоне; J. Радов, Ћутање је знак одобравања, Један дан са женом // Бубањ за горњи свет : од Белова до Ј. Садур / ур. М. Јовановић. - Београд : Плато, 2004. - Стр. 5-18, 256-263, 313-320, 336345. - (Антологија руске приче XX века ; 2, 2) (Библиотека Психократия)

8. Старица // Поезија. Проза и сцене. Драме. Дела за децу / Даниил Иванович Хармс. - Београд : Логос, 2005. - Стр. 544-562. - (Сабрана дела у два тома ; 0-1)

9. Чланци. Књижевни поступак на који наилазимо...; Записаћемо тактну структуру...; Концерт Емила Гилелса у Клубу писаца. Прилози : документарни материјал из полицијских архива, записници са саслушања // Трактати. Чланци. Писма. Бележнице. Дневник. Цртежи. Прилози / Даниил Иванович Хармс. Београд : Логос, 2005. - Стр. 37-43, 779-856. - (Сабрана дела у два тома ; 1-0)

10. Алтај - Хималаји : путописни дневник / Николај Константинович Рерих. - Београд : Логос, 2007. - 309 стр. - (Библиотека С оне стране)

11. Московска сага : трилогија. Књ. 3, Тамновање и мир / Василиј Аксјонов. - Београд : Информатика, 2008. - 478 стр. - (Дело ; 3)

12. Бројанице од жада : авантуре Ераста Фандорина у XIX веку / Борис Акунин. - Београд : Informatika, 2009. - 558 стр. - (Авантуре Ераста Фандорина) 